IRA-International Journal of Management \& Social Sciences

ISSN 2455-2267; Vol.07, Issue 02 (2017)

Pg. no. 286-293

Institute of Research Advances

http://research-advances.org/index.php/RAJMSS

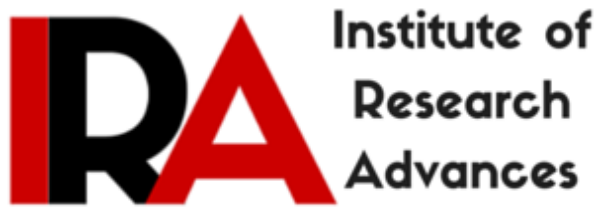

\title{
Television Advertisements Impact on Customer's Buying Behavior for the 'Health Drinks Which Makes Milk Richer of Children' In the Area of Vadodara City
}

\section{Dr. Sandip G. Prajapati}

Assistant Professor, Department of Commerce and Business Management, Faculty of Commerce, The Maharaja Sayajirao University of Baroda, Vadodara, India.

Type of Review: Peer Reviewed.

DOI: http://dx.doi.org/10.21013/jmss.v7.n2.p19

\section{How to cite this paper:}

Prajapati, S. (2017). Television Advertisements Impact on Customer's Buying Behavior for the 'Health Drinks Which Makes Milk Richer of Children' In the Area of Vadodara City. IRAInternational Journal of Management \& Social Sciences (ISSN 2455-2267), 7(2), 286-293. doi:http://dx.doi.org/10.21013/jmss.v7.n2.p19

(C) Institute of Research Advances

(cc) EY-NC

This work is licensed under a Creative Commons Attribution-Non Commercial 4.0 International License subject to proper citation to the publication source of the work.

Disclaimer: The scholarly papers as reviewed and published by the Institute of Research Advances (IRA) are the views and opinions of their respective authors and are not the views or opinions of the IRA. The IRA disclaims of any harm or loss caused due to the published content to any party. 


ABSTRACT
The concepts of health and energy have perhaps never been as popular-or pursued/coveted-as
they are now. With market rivalries becoming an intense affair, brand strategists and marketers are
eager to refresh their brand's positioning and image. The focus on functional health benefits has
allowed India to become the world's largest market for malt-based hot drinks with US\$1.1 billion in
2015 retail sales, with room for additional growth. In addition to health-oriented marketing
initiatives, growth of malt-based hot drinks in India has been aided by a young population, growing
knowledge of health and nutrition, and an increase in income. Primary objective behind conducting
this research is to find out at what extent television advertisements impact on customer's buying
behavior for the 'health drinks making milk richer of children's in the area of Vadodara city.
Descriptive single cross sectional research design was selected for conducting this research in the
area Vadodara city. Sample of 200 were chosen for conducting this research. For more effective and
accurate result, Stratified Random Sampling method was used as a sampling technique. Different
statistical tools were applied to analyze the data. Research reveals that; television advertisement has
substantial influence on children's and their papers. This will affect the moving product desire from
one brand to another.

Key Words: Television Advertisement, Consumer Behaviour, Health Drinks and Behavior of Children

\section{INTRODUCTION}

The concepts of health and energy have perhaps never been as popular — or pursued/coveted — as they are now ${ }^{1}$. With market rivalries becoming an intense affair, brand strategists and marketers are eager to refresh their brand's positioning and image. More often than not, it is the 'health' tag that becomes their 'open sesame' to the consumer universe. Certainly there is ambiguity to the whole thing and while companies may be tempted to use it to their advantage, as consumers we will be better off if we are aware of what we are consuming.

(LEE, 7th May, 2016)The focus on functional health benefits has allowed India to become the world's largest market for malt-based hot drinks with US\$1.1 billion in 2015 retail sales, with room for additional growth. By 2020, India is expected to account for $47 \%$ of global malt-based hot drinks retail volume sales, up from $41 \%$ in 2015 . Marketing initiatives such as age segmentation, combined with continued growth in GDP and population, are expected to contribute to an $8 \%$ retail volume CAGR for malt-based hot drinks for 2015-2020, up from the 7\% CAGR for 2010-2015. India's success with malt-based hot drinks represents a situation where a product category that has been around for decades is expected to grow faster over the forecast period than during the review period, due to the combined forces of greater income and nutrition knowledge.

SELECTED COUNTRIES: 2015 PER CAPITA RETAIL VOLUMES FOR MALT-BASED HOT DRINKS AND TOTAL HOT DRINKS

\begin{tabular}{|c|c|c|c|}
\hline Country & $\begin{array}{c}\text { Malt-based hot } \\
\text { drinks (kg) }\end{array}$ & Total hot drinks (kg) & $\begin{array}{c}\text { Malt-based hot drinks as } \\
\text { percentage of total hot drinks }\end{array}$ \\
\hline India & 0.2 & 0.4 & $50.0 \%$ \\
\hline Malaysia & 1.1 & 2.5 & $44.0 \%$ \\
\hline Singapore & 1.2 & 3.0 & $40.0 \%$ \\
\hline UK & 0.1 & 2.8 & $3.6 \%$ \\
\hline US & 0 & 2.7 & $0.0 \%$ \\
\hline
\end{tabular}

Source: Euromonitor International

In addition to health-oriented marketing initiatives, growth of malt-based hot drinks in India has been aided by a young population, growing knowledge of health and nutrition, and an increase in income. India has one of the youngest populations, with $29 \%$ of the country aged $0-14$-years-old in 2015 ,

\footnotetext{
${ }^{1}$ Retrieved from http://consumeraffairs.nic.in/consumer/writereaddata/Health_Drink.pdf on 21st March, 2017.
} 
compared to $26 \%$ for the world. The number of children aged 0-14 grew by $1 \%$ from 2010-2015 in India and is projected to grow by $0.5 \%$ from $2015-2020$. Growing health awareness and incomes have helped to increase demand for malt-based hot drinks among middle- and upper-class Indians.

Wider internet access has helped malt-based hot drinks companies expand their marketing beyond traditional advertising and event sponsorship, to offer nutrition and education tips on their websites. The Indian website for Horlicks, the leading malt-based hot drinks brand in the country, appeals to ambitious parents by offering an Educational Corner that provides video lessons on subjects such as biology, chemistry, mathematics, and physics.

Though India has a growing youth population, manufacturers are likely to use age segmentation to reach beyond the 5-14-year-old base. The number of Indians aged 5-14, the main consumer base for malt-based hot drinks in India, is expected to grow by $1 \%$ from 2015-2020, down from $2 \%$ for 20102015. To keep growing demand for malt-based hot drinks, GlaxoSmithKline has already extended its Horlicks family brand through a Junior Horlicks for children aged 1-3-years-old (1995), a Horlicks Lite for diabetics (2005), and Women's Horlicks (2008).

Major Players at India (Comparative Analysis)

Following is the list of major players in malt base health drinks and there target group.

\begin{tabular}{|l|l|l|l|l|l|}
\hline $\begin{array}{c}\text { Sr. } \\
\text { No. }\end{array}$ & \multicolumn{1}{|c|}{ Brand } & \multicolumn{1}{|c|}{ Type } & $\begin{array}{l}\text { Flavors/ } \\
\text { Categor } \\
\text { y }\end{array}$ & Brand Owned by & \multicolumn{1}{|c|}{$\begin{array}{c}\text { Manufacturer's } \\
\text { Recommendation }\end{array}$} \\
\hline 1 & $\begin{array}{l}\text { Complan } \\
\text { (NutriGro) }\end{array}$ & $\begin{array}{l}\text { Proprietary } \\
\text { food }\end{array}$ & $\begin{array}{l}\text { Chocola } \\
\text { te }\end{array}$ & Heinz India & For children 2-4 yrs old \\
\hline 2 & $\begin{array}{l}\text { Horlicks (Taller } \\
\& \text { Stronger) }\end{array}$ & Malt based & $\begin{array}{l}\text { Cocoa } \\
\text { powder }\end{array}$ & GlaxoSmithKline & For growing children \\
\hline 3 & $\begin{array}{l}\text { Bournvita } \\
\text { (Li'l Champs) }\end{array}$ & Malt based & $\begin{array}{l}\text { Vanilla } \\
\text { and } \\
\text { cocoa }\end{array}$ & Cadbury India & For children 2-5 yrs old \\
\hline 4 & Boost & Malt based & Cocoa & GlaxoSmithKline & $\begin{array}{l}\text { Increasing endurance and } \\
\text { stamina in children }\end{array}$ \\
\hline 5 & Amul (pro) & Malt based & Cocoa & GCMMF & For growing children \\
\hline 6 & $\begin{array}{l}\text { Complan } \\
\text { (Planned Food) }\end{array}$ & $\begin{array}{l}\text { Proprietary } \\
\text { food }\end{array}$ & $\begin{array}{l}\text { Chocola } \\
\text { te }\end{array}$ & Heinz India & For growing children \\
\hline
\end{tabular}

(M.Dijkstra, 2005)The strategies used by advertisers in the Indian television media are similar to those seen in other countries in that they make target-specific appeal to adults and children audience. Food advertisers tactically project their products in exclusive children television channels as compared to mainstream television channels. Families play an important role in the lives of young children who depend on them for nourishment, role modeling, and setting rules for various activities such as TV viewing and advertising exposure. It is important that parents be aware of the amount of advertising exposure their children receive and its impact on their food preferences.

\section{LITERATURE REVIEW}

Many scholars have at one time or the other attempted to explain the effects of television advertisement on the consumers generally, and the particular case of children.

Discussing about the television adverts and the children, (Baran, 2002), argued that adverts exploit children. According to him, children are not intellectually capable of interpreting the intent of televisions advert, nor are they able to rationally judge the worth of adverts claim. He sees children adverts on television as inherently unethical and questionable. He challenged parents who only resist to living sales people (hawkers) entering their homes to sell their children products, but allow the most sophisticated sales people to do it through a highly influential mass medium (television) to their children. 
Another scholar, (Vivian, 1997), cited a study on the effects of adverts, by Yankelovich partners who sampled 1,000 consumers of products, and found that television adverts have the highest percentage of influence on viewers, especially the young consumers (children). Apart from adverts, Vivian noted that recommendations from friends also induce children to patronize certain products. Supporting the above view, (J.R.Dominic, 1994), used a circular diagram to list some factors that influence or determine children's actions, viz:

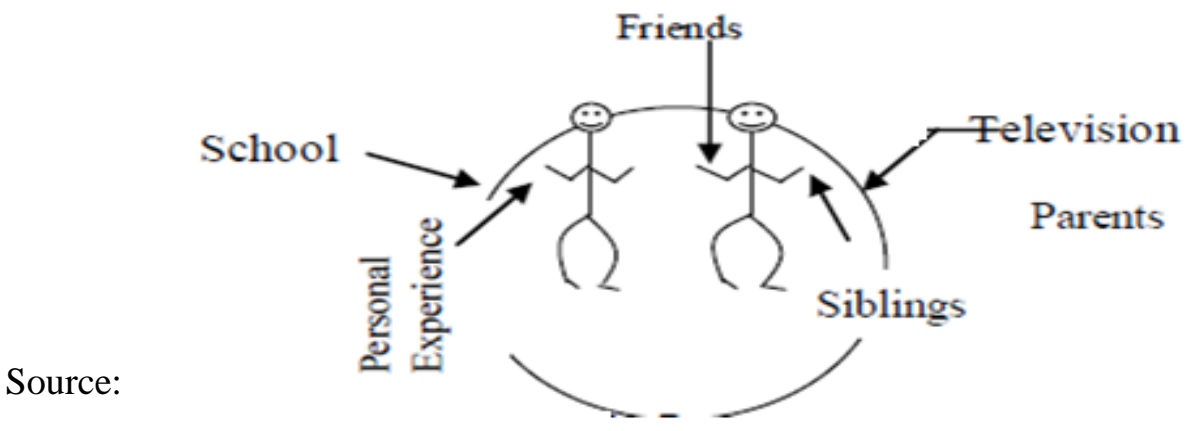

Dynamics of Mass Communication.
Dominic, J.R. (1994:513), the

In addition to the above factors, age and level of education are also influential factors on children's behaviors or actions. Among all these, (McNeal, 2001) cited a 1999 survey of television effects on kids by Yankelovich which revealed that effects of television adverts on children remain highest when compared to those of other mass media.

The American Association of Advertising Agencies (AAAA), as noted by (Baran J. a., 1995), studied the effects of advertising and discovered that our power of perception played much role on the way we view advertising. They noted that even though newspapers, magazines and radio adverts also have effects on consumers, our opinions are principally influenced by television adverts.

In his analysis, (Jefkins, 2000), contend that the persuasive mechanism employed by advertising professionals, make television adverts in particular to become highly irresistible especially to subtle minds like those of children who are generally known to be susceptible.

Referring to specific effects of television advertisement, (D. Shellaberger, 2003), condemned the attitude of television advertisers who sometimes advertise cigarette along with food. That cigarette advertisement on television promotes many young people smoking and enjoying themselves. Smoking has nothing reasonable to offer to children but health problems later on in life. Television impacts children the most as far as advertising goes. Consequently, children continue to hassle their parents until they get the things they had watched advertised on the television.

However, it would rather not make complete sense to look at one side of the coin. According to (McNeal, 2001), there are few television advertisements, which are beneficial to the children. For example, the ones that are selling educational books for children and other types of learning materials. Others that fall within this category include all forms of television adverts that discourage or reject acts of immorality or criminality such as premarital sexual relationship, stealing, cheating among others.

Summarily, television as a powerful mass medium is undoubtedly the most influential medium of mass communication. Its influence is noticed in almost every of its programmes - news, public announcements, or commercials/advertisements. Children viewers are therefore not exempted from the powerful influence of television. How the children usually react to the television advertisements, would be revealed at the end of this study. 
In their specific analysis of catharsis theory and media effects, (Baran J. a., 1995), asked: (i) when you watch couples engage in physical affection on the screen, does it reduce your sexual drive? (ii) Does media presentation of families devouring devilish chocolate purge you of your hunger drive? Their answers to these questions were simply no. Therefore, one could infer that when children watch television adverts of say, people fighting, playing football, eating a delicious meal, would rather make them develop appetite or interest on them, than hating or disliking what they watched.

\section{RESEARCH METHODOLOGY}

Primary objective behind conducting this research is to find out at what extent television advertisements impact on customer's buying behavior for the 'health drinks making milk richer of children's' in the area of vadodara city. Besides this some of the secondary objectives are To Check the impact of usage of brand ambassador in advertisement for nutrition drinks, to identify the most influencing media, right time for advertisement and right place for advertisement and to understand the awareness of consumers towards the ingredients of the nutrition drinks etc.

Research Design: Research Design: This study is intended to describe the effects or the communicativeness of television advertising on children. It counts the attitude, perception and behaviors of children and their parents. Descriptive single cross sectional research design was selected for conducting this research in the area Vadodara city.

Based on the survey research method used relevant findings were made. In his explanation, (Akuezuilo, 1993), said that survey research is one in which a group of people or items are studied by collecting and analyzing data from only a few people or items considered to be representative of the entire group.

Research instrument and approach: for conducting this research structured questionnaire were used for the purpose of collected primary data and personal interviews are conducted at respondents place.

Sampling Technique: For more effective and accurate result, Stratified Random Sampling method was used. In which Vadodara city was divided into four areas: Fathegunj, Raopura, Nizampura and Waghodiya. Explaining this method, (S. Olaita, 1988), asserted that different groups of a population are adequately represented in the sample so as to increase their level of accuracy when making judgment.

The Sample Size: for this study two hundred parents/children were considered. In each of the stratum, fiftyparents/children were sampled. Both primary and secondary data sources were used for the purpose of preparation of this paper.

\section{DATA ANALYSIS \& FINDINGS \\ Demographic detail:}

Out of total respondents $50 \%$ are of the age of $21-30$ whereas $23 \%$ are of the age of $31-40$ years. In the case of education, out of total respondents only $5 \%$ of respondents are having primary education. $14 \%$ of respondents are having Middle School education. 24\% of respondents are having High School education and $62 \%$ of respondents are College Graduate. In the cease of income $45 \%$ of respondents are having their Monthly family income 20000 to 30000. 15\% respondents are having their Monthly family income 30001 to 40000 and $40 \%$ respondents are having their Monthly family income above 40000. While 55\% of respondents is from Nuclear Family and $45 \%$ of respondents is from Joint Family.

\section{Data Analysis:}

$\checkmark$ Reasons behind adding flavors - 65\% of the respondent said that they use to prefer flavors because of the demand by the children and family members. Whereas $25 \%$ are adding flavor for the nutrition values and about $10 \%$ of the respondent are using for the taste purpose only. 
$\checkmark$ Which brands you prefer - 51\% of the respondents choose to buy bourn vita. While $17 \%$ of the respondent prefer to buy boost and another $15 \%$ choose to buy complan. While $15 \%$ of the respondent go for the horlicks brand and $2 \%$ only buy others brands.

$\checkmark$ If preferred Brand not available - 69\% said that they will buy the same brand from somewhere else. While at the same time $31 \%$ said that they will buy the product of another brand.

$\checkmark$ Rank the sources of awareness - Rank 1 Television advertisement, Rank 2 Word of mouth, Rank 3 News papers, Rank 4 Advertisement on radio, Rank 5 other sources.

$\checkmark$ Place to buy - 62\% of the respondent prefers to buy from the Kirana/ Provision shop near to their home. While $38 \%$ buy from the super market/Mall.

$\checkmark$ Attributes given priority - Rank 1 Nutrition value, Rank 2 Price, Rank 3 Brand, Rank 4 Promotional schemes/Gift and Rank 5 Brand Ambassador.

$\checkmark$ No of times observe Advertisement $-72 \%$ of the respondent states that they have been come across with the advertisement more than twice in a day while $28 \%$ of the respondent encountered with the advertisement less than twice a day.

$\checkmark$ Advertisement observed in - 59\% of the respondent said that the usually see more this type of advertisements on the Children specific channels like Cartoon network, Pogo, Disney etc. while $41 \%$ of the respondents observe this kind of advertisement on other general entertainment channels.

$\checkmark$ Awareness about ingredients - 69\% of the respondent said that they are aware about the ingredients. While only $32 \%$ said no that they are not aware.

$\checkmark \quad$ TV Add Influence buying - Here 92\% of the respondent said that yes advertisement is the best promotion media to reach the customer and it influence their buying. While $8 \%$ of the respondents said that there are other media also which influence more the customer as compare to the TV advertisement.

\section{Statistical Tools Applied: \\ Hypothesis Analysis}

$\checkmark$ H1:-There is no significant impact of the message conveyed through television ads is properly understandable and education level of the respondents. Here the significance value of the $\mathrm{F}$ test in the ANOVA table is .038 which is less than 0.05; therefore, null hypothesis is rejected. Hence there is significant difference of the message conveyed through television ads on education level of respondents. Hence the message conveyed through television ads is properly understandable has significant impact on education level of respondents.

$\checkmark$ H2:- There is no difference among comparison of two products with each other in television advertisement makes any impact on respondents buying behavior and the education level of the respondents. From the chi-square test output table we see that a p value is 0.470 which is greater than 0.05 . So null hypothesis is accepted. This means the chi-square test is showing that there is no difference among comparison of two products with each other in television advertisement makes any impact on respondents buying behavior and the education level of the respondents.

$\checkmark$ H3:- There is no difference among awareness about ingredients of the nutrition drinks which have been used and level of education of the respondents. From the chi-square test output table we see that $\mathrm{p}$ value is 0.153 which is greater than 0.05 . So null hypothesis is accepted. This means the chi-square test is showing that there is no significant impact of awareness about ingredients of nutrition drinks which has been used and the education level of the respondents.

\section{Factor Analysis:}

For identifying the impact of different variables or elements behind the impact of Television advertisement in buying behaviour factor analysis were used. By examining the Kaiser-Meyer-Olkin measure of sampling adequacy (MSA) was found to be 0.768 which is greater than required value of 0.5 or more for further analyzing data for factor analysis and also indicates that the sample was good enough. Bartlett's test of sphericity showed statistically significant number of correlations among the 
variables (Approx. Chi square $=1926.38, \mathrm{df}=21, \mathrm{Sig} .=0.000$ ). Also Bartlett's test of sphericity tests the null hypothesis that the correlation matrix is an identity matrix. An identity matrix is matrix in which all of the diagonal elements are 1 and all off diagonal elements are 0 . Here the null hypothesis is rejected. Rotated component matrix shows further reduced no. of variables. We have two components as variables:

Component 1 is highly loaded on, Seven factors first is television ad motivates children to drink flavored milk second is influence of popular personality to drink nutrition drink, third is children get influence from free gifts, fourth is negative impact on children by television ads of nutrition drinks, fifth is repetition of television ads is not necessary, sixth is television ads provide accurate information about the product and seventh is children influence to purchase a product after watching television ads. But, the loading on television ad motivates children to drink flavored milk is more than the other factors. So, this factor is better representative of these seven variables.

Component 2 is highly loaded on; three factors first are television ads provide only healthy aspects of the product. Second is ads comes at time when children watch their program. Third is message is properly understandable through television ads. But the loading on television ads provide only healthy aspects of the product is more than ads comes at time when children watch their program and message is properly understandable through television ads. So, television ads provide only healthy aspects of the product is better representative of these three variables.

\section{RECOMMENDATIONS}

Base on this research following recommendation can be made for different parties.

$\checkmark$ The government and other relevant bodies should establish effective and accurate guideline intended to promote accurate and true advertisement specific to the children. Some of the guideline noted by (Boush, 2001) .

$\checkmark$ Parents should keep control on commercials observed/watched by children's. They should regulate the TV shows and advertisements during it. Teachers on their part can also help and teach the Childers's about all television advertisements are not real.

$\checkmark$ Advertisers/ Advertisement made agencies must encourage for emphasizing good moral in their advertisement which are targeted to children's. They should come with programmes which help the children's in their education.

$\checkmark$ Religious Guru's should help to educate both parents and children on how to avoid consumption of advert messages in television, mobile, internet and other audio -visual media of communication.

$\checkmark$ Parents should identify alternative ways for their children to spend their free time. Motivate them to play out door games; spending time with the children saves children from a lot of troubles or dangers.

\section{CONCLUSION}

Base on findings, it is very clear that television advertisement have substantial influence on children's and their papers. This will affect the moving product desire from one brand to another. Effective advertisement can also influence well educated adults (parents). Research found that majority of the parents keep track on ingredients which is one of the most important factors while buying health drinks. In the case of buying health drinks children influence parents to purchase a product after watching television ads. Parents get influenced by their family, friend and children for purchasing a product. Comparative advertisements does not have any impact on consumer's buying decision which shows the consumer's satisfaction level for their current nutrition drink products.

At last, whether television advertising to children's is harmful or serves the economy by generating jobs and money. One thing is very clear the children's future life should be considered first and not the economy. 


\section{References}

Akuezuilo, E. (1993). Research Methodology and Statistics: NUC/NBTE/NCE Minimum Standard Edition. Awka: Nuel Centi (Nig.) Publishers.

Baran, J. a. (1995). Mass Communication Theory: Foundations, Ferment and Future. : Belmonth Calfornia: Wadsworth Publishing Co.

Baran, S. (2002). Introduction to Mass Communication. Boston: McGraw-Hill. Inc.

Belch, G. E. (2005). Advertising and Promotion. Tata MacGraw Hill (Sixth Edition).

Boush, D. M. (2001). Mediating advertising effects. New York: John Wiley and Sons Inc.

D. Shellaberger. (2003, November). Only Good Things Happen when you Advertised to Children". Retrieved March 21, 2017, from http://www.bgsu.edu2003.: http://www.bgsu.edu2003.

J.R.Dominic. (1994). The Dynamics of Mass Communication. New York: McGraw Hill Inc.

Jefkins, F. (2000). Advertising. New Delhi: MacMillan India Ltd.

LEE, V. (7th May, 2016). Health Positioning Leads to Strong Growth of Malt-Based Hot Drinks in India. South Korea: euromonitor.com.

M.Dijkstra, E. W. (2005). "Separate and joint effects of medium type on consumer responses: A comparison of television, print and the internet". J Bus Res, vol. 58, pp 377-386,.

Malhotra, N. K. (2005). Marketing Research: An Applied Orientation. Pearson Education (Fourth Edition).

McNeal, C. M. (2001). Call it Kid-fluence U.S. U.S.

S. Olaita, a. G. (1988). Practical Research Methods in Education . Onitsha: Summer Education Publisher ltd.

Schiffman, L. G. (2005). Consumer Behavior. Pearson Education (Ninth Edition).

Vivian, J. (1997). The Media of Mass Communication (4th ed.) . London: Allyn and Bacon. 